\title{
DROGA NA ZESŁANIE POLSKICH KOBIET RAZEM Z DZIEĆMI PO POWSTANIU STYCZNIOWYM ${ }^{1}$
}

Streszczenie. Jedną z najsurowszych kar po powstaniu styczniowym było zesłanie na Sybir. Polacy wbrew swej woli musieli przebyć tysiące kilometrów w drodze na wschód. Oprócz skazanych mężczyzn, znajdowały się tam kobiety - Polki. W historiografii poświęcono niewiele miejsca dziejom polskich zesłanek, które zdecydowały się towarzyszyć swoim bliskim, bądź trafiły w głąb państwa carów za swoją działalność polityczną.

Jeden z wątków „kobiecej podróży” jest szczególny, mianowicie podróż na zesłanie z dziećmi. Problemy aprowizacyjne, bezduszność rosyjskich urzędników, choroby oraz fatalne warunki noclegowe to tylko niektóre z problemów na jakie natrafiały matki.

Celem niniejszego artykułu, jest przybliżenie warunków z jakimi musiały zmagać się kobiety w drodze na Syberię oraz w głąb Rosji. Uchwycenie tragedii oraz roli Polek, które z poświęceniem własnego życia, starały zapewnić jak najbezpieczniejszą podróż swoim dzieciom.

Słowa kluczowe: Syberia, XIX wiek, Polki, zesłanie, Powstanie Styczniowe, exile, Siberia, Polish women.

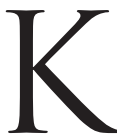

lęska powstania styczniowego sprowadziła na społeczeństwo polskie represje ze strony rosyjskich władz. Jedną z najdotkliwszych kar było zesłanie na Syberię - ziemię uchodzącą za niecywilizowaną, o wyjątkowo niesprzyjającym klimacie. Wśród zesłańców znajdowały się także kobiety. Część z nich została skazana za swoją działalność polityczną. Były to najczęściej konspiratorki, kurierki aktywnie angażujące się w walkę z rosyjskim zaborcą. W tej grupie znajdowały się także całe rodziny, skazywane za

${ }^{1}$ Artykuł został przygotowany w ramach Stypendium Cieszkowskiego (tytuł realizowanego projektu: „Polskie kobiety na Syberii w latach 1830-1883”). 
pomoc powstańcom. W tym wypadku nie było możliwości wyboru, należało udać się tam, gdzie skierował wyrok imperialnego sądu. Drugą grupę stanowiły kobiety, które towarzyszyły swoim bliskim w zesłaniu. Najczęściej były to żony skazańców, chociaż zdarzały się także matki i córki. Należy zaznaczyć, że była to przede wszystkim ich dobrowolna decyzja, zależna od chęci i uczuć żywionych wobec rodziny. Oczywiście podjęcie jej nie było łatwe, kobieta decydując się na wyjazd, musiała liczyć się z pozbawieniem przysługujących jej praw.

Problematyka obecności polskich kobiet na Syberii wzbudza coraz większe zainteresowanie wśród badawczy polskich i rosyjskich, niemniej nie doczekała się jeszcze wyczerpującego opracowania i wymaga dalszych pogłębionych studiów ${ }^{2}$. Wynika to przede wszystkim ze skąpej bazy źródłowej i jej rozproszenia. Pamiętniki i listy kobiet obrazujące zesłańcze losy należą do rzadkości ${ }^{3}$. Wspomnienia są ciekawym materiałem źródłowym do badań nad historią drogi na zesłanie, a także warunkami życia codziennego na Syberii. Opis podróży, zazwyczaj jest niezwykle rozbudowany, co dowodzi jego znaczenia. Można zaryzykować stwierdzenie, że był to pewnego rodzaju moment przełomowy - kobiety w wyniku życiowych perturbacji musiały opuścić rodzinne domy.

Jeden z wątków „kobiecej podróży” jest szczególny, mianowicie podróż na zesłanie z dziećmi. Celem niniejszego artykułu jest przybliżenie warunków, z jakimi musiały zmagać się matki w drodze na Syberię czy w głąb Rosji. Było to tym trudniejsze, że w związku z tym, że ich mężowie byli więźniami, niemal całkowity ciężar opieki nad dziećmi należał do obowiązków kobiet.

Dzięki postępowi technologicznemu w XIX wieku warunki podróży uległy znacznej poprawie. Kolej sprawiała, że podróż z więzienia w Warszawie czy Wilnie do Petersburga lub Moskwy ulegała skróceniu. Dalej jednak należało

2 Vide m.in.: W. Śliwowska, Polska - Syberia. Dwa światy w oczach polskich zesłanek, [w:] Polska a Syberia. Spotkanie dwóch Światów. Materiały z konferencji naukowej. Łódź 1-2 marca 2001 roku, red. M. Blomberg, Łódź 2001, s. 191-200; eadem, Polskie zesłanki na Syberię $w$ dobie międzypowstaniowej, „Miscellanea Historico-Archivistica” 1996, t. 6. s. 175-183; L. Michalska-Bracha, Syberyjskie doświadczenia Polek $w$ świetle materiałów Marii Bruchnalskiej - zarys problematyki, [w:] Polacy w nauce, gospodarce i administracji na Syberii $w$ XIX i na początku XX wieku, red. A. Kuczyński, Wrocław 2007, s. 131-138; W. Caban, Dom syberyjski polskich zesłańców politycznych w latach czterdziestych-siedemdziesiątych XIX wieku, [w:] idem, Powstanie styczniowe. Polacy i Rosjanie w XIX wieku. Wybór studiów z okazji czterdziestolecia pracy naukowej i 65 rocznicy urodzin, Kielce 2011, s. 369-378.

${ }^{3}$ M.in. J. Prendowska, Moje wspomnienia, Kraków 1962; M. Obuchowska-Morzycka, Pamiętniki, [w:] J. Klijanienko-Pieńkowski, Pan Pieńkowski? Da, oni zili zdieś... Wołyń, Syberia, Nałęczów, losy ziemiaństwa na podstawie dokumentów rodzinnych, Stalowa Wola 2012, s. 86-422; z kobiecych wspomnień warto jeszcze wyróżnić E. Felińska, Wspomnienia z podróży do Syberii, pobytu w Berezowie i Saratowie; spisane przez Ewę Felińska, Wilno 1852-1853, t. 1-3. 
wyruszyć powozem lub pieszo, ewentualnie jeśli warunki na to pozwalały, można było część drogi przepłynąć statkiem. Aby lepiej zobrazować odległość jaką musiały przebyć Polki udające się na zesłanie warto zacytować obliczenia Elżbiety Kaczyńskiej:

Jeśli skazany szedł z Ukrainy, to z Kijowa przez Orzeł do Moskwy pokonywał 900 km. Stąd do Niżnego Nowogrodu było 500 km, z Niżnego do Kazania - 350 km, z Kazania do Permu 630 km. Kolejne odcinki drogi pieszej, które dopiero od 1887 r., można było stopniowo zastępować transportem kolejowym, wynosiły: Perm - Jekaterynburg $660 \mathrm{~km}$, Jekaterynburg - Tiumeń 350 km, Tiumeń - Tomsk 1660 km, Tomsk - Irkuck 1700 km. [...] Polacy z Królestwa Polskiego przebywali drogę wynoszącą często 14,5 - 16 tys. km, nie licząc dojścia od centrum administracyjnego, gdzie byli rejestrowani, do wsi wyznaczonej na zamieszkanie ${ }^{4}$.

Ogromna liczba kilometrów do przebycia przez rosyjskie ziemie, należała do najcięższych wyzwań z jakimi mierzyli się zesłańcy. Wobec tak dużych odległości czas podróży był różny. Mogła trwać zarówno kilka miesięcy, jak i nawet lata. Wszystko zależało od pogody, stanu zdrowia zesłańca, stosunku miejscowych władz. Należało zatem przygotować się odpowiednio do drogi. W tym celu jeszcze przed wyjazdem kobiety wyprzedawały część majątku, aby uzyskać niezbędne środki finansowe. Należało zaopatrzyć się w jak najwięcej niezbędnych produktów, do maksimum wykorzystując miejsce na bagaż. Najczęściej zabierano ciepłe ubrania, kołdry, niezbędną bieliznę, suchy prowiant ${ }^{5}$. Wobec ogromu drogi do przebycia zawsze można było część rzeczy sprzedać, uzyskując pieniądze na łapówki. Te ostatnie mogły znacząco ułatwić podróż.

Pierwszym etapem $\mathrm{w}$ drodze na zesłanie było $\mathrm{w}$ wielu wypadkach więzienie, bądź spotkania z rosyjskimi urzędnikami. Honorata Gembicka obawiając się aresztowania, postanowiła sama ubiegać się o możliwość wyjazdu za zesłanym mężem ${ }^{6}$. W tym celu wraz z córką musiały stawić się do generał-gubernatora w Kownie, którym w ówczesnym czasie był owiany złą sławą Michaił Murawiow „Wieszatiel”" Po nieuprzejmym przyjęciu, Honorata

${ }^{4}$ Ibidem, s. 105.

${ }^{5} 0$ wyprzedażach inwentarza z majątku wspominają m.in. M. Morzycka-Obuchowska, Wspomnienia..., Stalowa Wola 2012, s. 159-160; oraz S. Gembicka-Trębicka, Na nieznane losy. Między Ołońcem a Jadryniem. Dwa pamiętniki z zesłania po powstaniu styczniowym, oprac. A. Brus, Warszawa 1999, s. 298.

${ }^{6}$ Kobieta zdawała sobie sprawę, że jeśli nie pojedzie za mężem może zostać zesłana do innej guberni. Ostrzegł ją przed tym, za łapówkę pułkownik Antipow. Vide: Ibidem, s. 297.

7 Gembickie, aby stawić się przed gubernatorem, musiały ubrać się w jasne rzeczy, wbrew powszechnie obowiązującej żałobie po klęsce powstania. Gembicka zostawia dokładny opis wyglądu Murawiowa: „W drzwiach stanął Muraw[iow]: mężczyzna krępy o twarzy czerwonej, 
wręczyła prośbę adiutantowi generała. Odpowiedź otrzymały po dwóch dniach u pułkownika Żrebcowa. Ten zgodził się na ich wyjazd, zażądał jednakże podpisu zarówno matki, jak i kilkuletniego dziecka, o zrzeczeniu się możliwości powrotu ${ }^{8}$. Łatwo sobie wyobrazić przerażenie w momencie podpisywania tzw. „wilczego biletu”, zakazującego powrotu do kraju. Było to specyficzne, niezwykle surowe rosyjskie prawo, obejmujące rodziny towarzyszące zesłańcom. Bliscy osoby skazanej musieli się decydować na wielkie wyrzeczenie.

Nieco inaczej wyjazd z kraju zapamiętała Jadwiga Ostromęcka, wspominała, że znajoma rodziny Eliza Orzeszkowa podarowała dzieciom koszyk łakoci. Prezent stał się dla rodziny symbolem utraconego kraju. Przez długi czas w Tomsku znajdował się wśród zabawek ${ }^{9}$. Dodatkowo Ostromęckim w drodze na Syberię towarzyszył były zesłaniec, co niewątpliwie ułatwiało podroż:

Matka postanowiła dzielić z ojcem wygnanie. Nie wolno jednak było odbyć razem tej podróży, gdyż ojca wysłano etapem z partią. Daleka podróż, której znaczna część odbywała się końmi po kraju niemal pierwotnym, z trojgiem dzieci, z których najstarsza córeczka miała 7 lat, a najmłodsza 2 lata, byłaby zbyt uciążliwa, gdyby nie przywiązanie do siostry zacnego wuja Ludwika Łopocińskiego ${ }^{10}$. Znał już ten szlak drogi, którą odbył w swoim czasie za udział w kampanii węgierskiej, postanowił opieką swą otoczyć nas aż do miejsca wyznaczonego na wygnanie syberyjskie, a z niezrównaną pogodą ducha dodawać otuchy ${ }^{11}$.

Opieka nad dziećmi wymagała wielkiego poświęcenia. Problemy z aprowizacją odbijały się na najmłodszych. Dzieci często chorowały, były niedożywione, $\mathrm{w}$ wyniku czego groziła im śmierć. $\mathrm{W}$ etapach panowały fatalne warunki sanitarne, co sprzyjało rozwojowi epidemii. Pochodząca z Litwy Katarzyna Nowicka w drodze na zesłanie straciła czworo dzieci oraz męża.

szedł ku nam przez długość sali, staną tuż i wpatrywał się w nas zielonymi oczami tak uporczywie, że wprost przykuwało do ziemi. Zdawało mi się, że stoję na rozżarzonych węglach, cała sala i Murawiow zaczęły mi wirować w oczach. Nareszcie padło jedno słowo z grubych warg gubernatora: Czewo?!", [w:] S. Gembicka-Trębicka, Na nieznane losy..., s. 298-299.

8 Ibidem, s. 299.

9 J. Ostromęcka, Pamiętnik z lat 1862-1911, Warszawa 2004, s. 35.

10 Łopaciński Ludwik - uczestnik powstania listopadowego, następnie przebywał na emigracji we Francji. W 1849 r. przybył do Krakowa, gdzie został zatrzymany i przekazany władzom rosyjskim. Na mocy decyzji Iwana Paskiewicza wcielony do Korpusu Syberyjskiego bez utraty praw stanu. W 1856 roku awansował na podoficera, otrzymał dymisję i wrócił do guberni kowieńskiej. Vide: Zesłańcy polscy w Imperium Rosyjskim w pierwszej połowie XIX wieku, s. 347.

11 J. Ostromęcka, Pamiętnik..., s. 35. 
Spotkał ją na statku płynącym do Kazania Emil Dybowski. Kobieta była wynędzniała, z obłąkanym wzrokiem i dwójką małych dzieci przy sobie. Trudy podróży oraz utrata bliskich doprowadziły ją do zaburzeń psychicznych. Wyglądała na tyle „biednie”, że w pierwszej chwili Dybowski wziął ją za więźniarkę kryminalną i Rosjankę ${ }^{12}$.

Z problemem braku żywności, a raczej dostępu do niej, spotkała się Leonilda Lubiczanowska w wileńskim więzieniu. Lubiczanowska trafiła do wspólnej celi z dwójką dzieci: dwuletnią Jadwigą i kilkumiesięczną Anną. Gdyby nie pomoc jednej z kobiet, która przynosiła jej posiłki, Leonilda razem $\mathrm{z}$ córkami głodowałyby ${ }^{13}$. Także w dalszej podróży rodzina Lubinaczowskich miała kłopoty ze zdobyciem odpowiedniego jedzenia dla dzieci. W drodze do Pskowa, musiały jeść solone śledzie, ponieważ nic innego nie udało się kupić $^{14}$. Brak odpowiedniego pożywienia powodował problemy żołądkowe. W konsekwencji mógł doprowadzić do groźnego zatrucia, a w skrajnych wypadkach nawet do śmierci.

Maria Morzycka podróż odbywała będąc w ciąży. W marcu 1864 roku jej stan był na tyle zaawansowany, że postanowiła razem z Julianem poprosić władze o pozostanie w Tambowie. Morzycka sama zgłosiła się do gubernatora, ten zaś wyraził zgodę. Kobieta spodziewała się, że urodzi dziecko w czerwcu. Wobec tego rodzina zaczęła szukać akuszerki, oraz miejsca gdzie Maria mogłaby zatrzymać się na czas rozwiązania. Rosyjskie władze okazały się wyjątkowo pomocne. Zapewniły jej pokój u miejscowego urzędnika, a także przed samym porodem, dorożkę z zaprzężonym koniem, która miała przywieźć doktora i akuszerki. Po porodzie jedna z kobiet, przez trzy dni opiekowała się Marią. Po tym czasie Polka została niemal całkowicie sama. Z rzadka odwiedzała ją żona smotritiela, Julian nie został wypuszczany $\mathrm{z}$ więzienia. Wobec tego już piątego dnia po urodzeniu córki, której dano na imię Faustyna, Morzycka musiała wstać z łóżka. W ciągu kolejnych dni była zmuszona do prania pieluch, co nie wpływało dobrze na zdrowie osłabionej kobiety. Opieka nad dzieckiem wymagała przewijania, karmienia i doglądania niemowlęcia. Dlatego też ósmego dnia postanowiła przenieść się na powrót do więzienia, do męża. Ten mógł nieco odciążyć Marię od obowiązków ${ }^{15}$.

Nie były to jedyne problemy, z jakimi musiała zmagać się Maria. Morzyccy oczekiwali na przyjazd starszej córki Róży. Sześcioletnia dziewczynka miała

12 E. Dybowski, Pamiętnik, Warszawa 2017, s. 50.

${ }^{13}$ B. Chomska z Lubiczanowskich, Pamiętnik Bronisławy z Lubiczanowskich Chomskiej z zesłania w guberni ołonieckiej w latach sześćdziesiątych i siedemdziesiątych XIX wieku, [w:] Na nieznane losy między Ołońcem a Jadryniem; dwa pamiętniki z zesłania po powstaniu styczniowym, oprac. A. Brus, Warszawa 1999, s. 79.

${ }^{14}$ Ibidem, s. 81.

${ }^{15}$ M. Obuchowska-Morzycka, Pamiętniki..., s. 175. 
dojechać do nich razem z rodziną Sejferdów. Okazało się jednak, że do spotkania nie dojdzie w Tambowie. Władze nie zezwoliły Julianowi na dłuższy pobyt. Rodzice spodziewali się, że uda się odebrać córkę w następnym mieście - Kiersanowie. Niestety plan ten nie powiódł się. Dopiero w kolejnym miasteczku, dziecko przywiózł pewien Rosjanin o nazwisku Skopin, którego poprosili o to Sejferdowie Dla Róży podróż z obcym, dorosłym okazała się traumą. Dziecko nie chciało jeść, ani mówić do Skopina, dziewczyna była przerażona jego rosyjską mową, a także tym, że wiózł ją w nieznaną dal ${ }^{16}$.

Podróż etapami z dwójką małych dzieci była koszmarem. Codzienne poranne zbiórki związane z liczeniem więźniów, następnie kilkugodzinna jazda wozem, by wieczorem znowu czekać na wejście do turmy, powodowały zmęczenie zarówno dorosłych, jak i dzieci. Morzycka wspominała:

Jak zwykle o czwartej czy piątej wyszliśmy z półetapu, ażeby przejść wiorst 15 po wypiciu naprędce herbaty i przekąsce na przystanku, czyli tak zwanym „priwale”. Do godziny 6 wieczór nie jedliśmy wcale. Faustyna ciągnęła niemiłosiernie na próżno, męcząc pierś pozbawioną pokarmu, smoczek wetknięty w próżną butelkę, bo mleka zabrakło, nie zadawalniał ją, gniewała się, krzyczała, a tu tymczasem stanęliśmy przed „guberskim prawieniem”. Po kolei wzywali więźniów i dawali każdemu ciepłe ubranie, choć partia nasza nie była wielka. Ja tylko jedna kobieta znajdowałam się pomiędzy politycznymi więźniami, jednak przeciągała się ta procedura zbyt długo, już się zupełnie ściemniło, godzina może była piąta, siedziałam na furgonie zdesperowana, nie mogąc sobie dać rady z płaczącem dzieckiem. Rózia zaczęła płakać, ja również zalałam się łzami i tak wszystkie trzy zawodziłyśmy z bezsilności ${ }^{17}$.

Także noclegi w budynkach etapowych, powodowały stres u matek. W zimie, zła wentylacja pomieszczeń mogły spowodować zaczadzenie dzieci, mniej odpornych od dorosłych. Piece nie opalane całymi tygodniami, zapychały się. W wyniku tego w pokoju zaczynał unosić się dym, a tym samym zaczynało brakować powietrza ${ }^{18}$.

Czasem jedynym ratunkiem okazywała się bezinteresowna pomoc napotkanych ludzi. W Penzie Maria poznała pochodzącą z Białorusi Ciechanowską - zesłaną tam administracyjnie. Kobieta była bogata oraz wpływowa, ponieważ była znajomą miejscowego gubernatora. Korzystając z tego pomagała więźniom, udającym się na Syberię. Widząc fatalny stan Morzyckiej oraz

16 Ibidem, s. 181.

17 Ibidem, s. 182.

18 Izabela z Sucheckich Kuncewiczowa wspominała swoje doświadczenia z etapem. W połowie grudnia razem z matką dotarły do Woroneża. Doszło tam do przykrego incydentu i niemal śmierci kobiet przez zaczadzenie w miejscowym hotelu. W skutek tego musiały kilka dni zostać w mieście i nabrać sił. Vide: „Bluszcz” 1926, nr 48, s. 1539. 
jej dzieci, Ciechanowska zaprosiła ją do swojego domu i zaopiekowała się nimi, na czas pobytu w mieście. Ponadto Ciechanowiecka, znalazła mamkę dla Faustyny. Prawdopodobnie, gdyby nie to, dziewczynka zmarłaby w dalszej drodze, ponieważ Morzycka nie miała pokarmu ${ }^{19}$.

Honorata Gembicka dojechała do męża w Moskwie i tam zamieszkała razem z nim i córką w więzieniu, oczekując na dalszą drogą do Jardynia. Aby tego dokonać kobieta złożyła wizytę u księcia Obolińskiego, który odpowiadał za los więźniów politycznych. Mające przykre doświadczenia z Murawiowem, kobiety spodziewały się nieuprzejmego potraktowania, czy wręcz wrogości. Jednakże książę Oboliński posiadał europejskie maniery, matka Gembickiej porozumiewając się łamanym rosyjskim, a w zdecydowanej większości po francusku, starała się dowiedzieć czy jej mąż jest już w Moskwie i w jakim więzieniu przebywa. Zauważywszy, że kobiety są same w obcym mieście, książę wydał instrukcje dotyczące ich noclegu. Po trzech dniach pobytu w Moskwie, Honorata dostała zgodę na widzenie się ze skazanym oraz możliwość zamieszkania z nim. Od tej pory Gembickie stały się więźniarkami ${ }^{20}$.

Oczywiście spotkanie z ojcem wywołało falę wzruszenia. Rodzina w końcu znowu znajdowała się razem. Z relacji Sabiny można dowiedzieć się jak wyglądało życie w titowskich koszarach. Pod koniec dnia w więzieniu odbywała się zbiórka, gdzie liczono skazańców ${ }^{21}$. Izba więzienna była mała, dodatkowo przepełniona. W celi Gembickich oprócz nich znajdowały się jeszcze trzy rodziny, aby zapewnić sobie odrobinę prywatności, oddzielały się improwizowanymi parawanami wykonanymi z prześcieradeł czy też dywanów, które zostały zabrane jeszcze z Polski. Pobudka odbywała się o szóstej rano, pół godziny było przeznaczone na sprzątnięcie prycz oraz ubranie się, następnie należało stawić się na zbiórkę, gdzie znowu liczono więźniów. Po tych czynnościach, władza pozwalała więźniom na względną swobodę. Jak podaje Gembicka mogli oni cały dzień chodzić po podwórzu, zakazane za to było gromadzenie się. Jeśli zeszło się dwóch, czy trzech więźniów rozganiał ich żołnierz ${ }^{22}$.

Opieka nad dziećmi wymagała uwagi przez całą dobę. Konstancja Łozińska jechała z małym synem, jej pierworodnym. W podróży przygotowywała

${ }_{19}$ M. Obuchowska-Morzycka, Pamiętniki..., s. 185-186.

${ }^{20}$ Koszary Titowskie były dobrze znane polskim zesłańcom. Budynek należący niegdyś do zamożnego kupca Titowa po jego bankructwie przeszedł na własność rządu, który to przerobił go na więzienie. Panowały tam dość względne warunki i swoboda, zwłaszcza jeśli miało się pieniądze. Vide: Nad nieznane..., s. 300.

${ }^{21}$ Jak wspomina Gembicka: „liczono nas w ten sposób, że szedł żołnierz i każdego szturchnqqwszy w plecy liczył: adin, dwa, itd.", Ibidem, s. 302.

${ }^{22}$ Ibidem, s. 306. 
dwa razy dziennie kluski do mleka. Nie pomagał jej w tym mąż Bolesław. Zazwyczaj mężczyźni jedynie w niewielkim stopniu wyręczali swe żony. Cały trud organizacyjny spadał na kobiety ${ }^{23}$. Wynikało to przede wszystkim z tego, że jako więźniowie, nie mogli swobodnie się poruszać. Tymczasem zdarzało się, że zdobycie pożywienia wymagało wyjścia w miasto.

Warto dodać, że po całodziennej wędrówce, wieczorem więźniowie mogli odpocząć. Tymczasem kobiety nadal musiały zajmować się dziećmi. Wspominała o tym Elżbieta Tabeńska, która w Moskwie została zamknięta z kobietami pochodzącymi ze Żmudzi:

Samych dzieci, po większej części malutkich, było w naszej izbie czterdzieścioro! Płakały one w nocy; powietrze było złe, duszne; nad rankiem kiedy dzieci ucichły, to znów ich matki zaczęły śpiewać godzinki; [...] ale nie wtedy gdy się spać po zmęczeniu chciało ${ }^{24}$.

Obecność dzieci męczyła zarówno matki, jak i pozostałe więźniarki. W kobiecych celach panował tłok i hałas. Płacz niemowląt był nieodłącznym elementem moskiewskiego więzienia przesyłowego. Nie wiadomo, czy na tym tle dochodziło do konfliktów. Najprawdopodobniej nie w przypadku Polek.

Dzisiaj nie sposób ustalić śmiertelności wśród kobiet i dzieci jadących na Syberię. Możemy jedynie przypuszczać, że występowała ona szczególnie wśród najbiedniejszych rodzin. Pieniądze ułatwiały przeżycie, choć i one nie pomagały w przypadku epidemii.

Kraśnikowie zostali w Kazaniu ze względu na chore dziecko - syna Kazia mającego trzy lata. Miejscowy lekarz sam nie przychodził do więzienia, wobec tego ojciec chłopca musiał codziennie nosić go do szpitala, pod okiem czterech żołnierzy. Doktor nie przykładał się specjalnie do leczenia chorego. Opatrywał Kazia i zapisywał jedynie te leki, które znajdowały się w rządowej, słabo wyposażonej aptece. Kraśnik próbował przekupić lekarza oferując pieniądze za leki przywożone z miasta, ten jednak nie wyraził zgody zasłaniając się przepisami. Wobec tego, chłopiec nie wracał do zdrowia. Tragedia nastąpiła podczas prawosławnych świąt wielkanocnych, Doktor rosyjskim zwyczajem świętował je przez tydzień, dodatkowo przedłużając swój urlop do $14 \mathrm{dni}$. Wówczas wszyscy chorzy pozostali bez opieki. Choroba dziecka wzmagała się coraz bardziej, rodzice żądali, aby za ich własne fundusze pozwolono sprowadzić doktorów miasta. Niestety rosyjscy urzędnicy nie chcieli pomóc Polakom, sugerując, że jest to poza ich kompetencjami. Nakazali napisać prośbę do gubernatora, którą osobiście miał doręczyć naczelnik

${ }^{23}$ K. Łozińska, Listy do obojga rodziców 1863-1876, BJ rkps 6940 III.

${ }^{24}$ E. Tabeńska, Z doli i niedoli. Wspomnienia wygnanki, Kraków 1897, s. 58. 
więzienia. Chłopiec czuł się coraz gorzej, nie mógł wstawać o własnych siłach. Kobieta i jej mąż byli całkowicie załamani obojętnością władz rosyjskich. Po czterech dniach przyszła odpowiedź gubernatora. W liście pisał on, że nie może pozwolić na to, aby do podejrzanych więźniów przychodzili lekarze z miasta, tym bardziej że w więzieniu jest apteka. Negatywna odpowiedź oznaczała powolną śmierć dziecka. Władza okazała się bezlitosna, pomimo tego, że Kraśnikowie sami chcieli opłacać pomoc lekarską, nie dane im było uratować syna ${ }^{25}$.

Oczywiście obecność dzieci, czasem mogła wpływać na nieco lepsze traktowanie. Pozytywne gesty wobec nich nie mogą jednak przysłonić prawdziwych trudów, z jakimi musiały zmagać się rodziny, a zwłaszcza kobiety podróżujące w ten sposób.

W drodze na zesłanie nie pomagały także różnice kulturowe. Polki szokował stosunek Sybiraczek do własnych dzieci. Wśród najniższych stanów przeważały wielodzietne rodziny, gdzie matki nie zajmowały się wcale swoim potomstwem. W związku z tym, a także z innych powodów, panowała wysoka śmiertelność. Niektóre z Rosjanek traktowały macierzyństwo jako szczególnie uciążliwe zajęcie, przeszkadzające w interesach. Jadwiga Prendowska wspominała:

Gdy naszej gospodyni umarło maleństwo, a ja ubolewałam nad jej zmartwieniem, odpowiedziała mi: - «A, pani, cóż tam takiego, dziecko to tylko kłopot, przeszkadza w handlu». Raz pod moim oknem dwie kobiety żywo rozmawiały, dosadnie gestykulując; przyglądam i przysłuchuję się, aż jedna z nich podnosi chustkę i pokazuje drugiej maleńką trumienkę, którą sama niesie zakopać, rada, że pozbyła się kłopotu.

Prendowska tęskniąca za dziećmi w Polsce, nie mogła sobie wyobrazić, że tak zachowują się matki ${ }^{26}$. Polka wspominała także, że płaczącym dzieciom, Sybiraczki podawały wywar z maku na uspokojenie. Nierzadko kończyło się to śmiercią niemowlaka. Zachowanie Sybiraczek wywoływało strach u Polek.

Trudy drogi były na tyle uciążliwe, że wielu zesłańców rezygnowało ze sprowadzenia swojej rodziny. Zdawali sobie sprawę, że podróż może doprowadzić do śmierci ich najbliższych. Leon Krupecki w liście do żony napisał, żeby nawet nie myślała o przyjeździe do niego do Werchoturyi, tym bardziej z dziećmi. Uważał, że droga zamęczyłaby je, i naraziła na masę nieprzyjemności i niebezpieczeństw. Dodatkowo na końcu wędrówki czekałoby rozczarowanie związane z brakiem cywilizacji (sto kilka chałup drewnianych i okolica bez doktora). W zamian za to proponował rodzinie udanie się do

${ }^{25}$ L. Jastrzębiec Zielonka, Wspomnienia z Syberii od roku 1863-1869, s. 274-278.

${ }^{26}$ J. Prendowka, Moje..., s. 278. 
Drezna, gdzie dzieci mogłyby uczyć się mówić po niemiecku. List ciekawie prezentuje obraz Syberii w kontrze do świata zachodniego.

Pobyt na Syberii nie mógł służyć rozwojowi, wywołał jedynie rozczarowanie i przygnębienie. Nie był też dobrym miejscem dla kobiet i dzieci. Zwłaszcza że w związku z brakiem możliwości porządnej edukacji narażone były na intelektualne straty z powodu braku odpowiednich nauczycieli, ale też i bibliotek ${ }^{27}$.

Podobne odczucia towarzyszyły Janowi i Marcelinie Bogdanowiczom. W listach do rodziny rozważali sprowadzenie swoich dzieci na Syberię, zwracali jednakże uwagę na wiele trudności z tym związanych. Na pierwszym miejscu wymieniali koszty podróży, które nie pozwalały na realizację tego zamiaru. W kolejnych listach wracali do pomysłu m.in. zakładając, że Marcelina wróci do kraju i przywiezie ze sobą dzieci. Ostatecznie wyperswadowała to Janowi jego matka, zwracając uwagę na stan zdrowia synowej, a także obawiając się o zdrowie wnuków ${ }^{28}$.

Macierzyństwo podczas drogi na zesłanie było trudnym doświadczeniem. Odbijało się ono także na wyglądzie kobiet. Wymęczone i wynędzniałe z wychudzonymi dziećmi na rękach, wzbudzały powszechny szacunek. Ich osobiste tragedie pozostają trudne do uchwycenia. W najgorszej sytuacji były rodziny przymusowo zsyłane z Litwy, którym zostały odebrane majątki. Nie posiadając środków finansowych, zdane były na niewydolny carski system. Najprawdopodobniej to właśnie wśród nich śmiertelność dzieci była najwyższa. Swoje żniwo zbierały także epidemie panujące w rosyjskich więzieniach. Najmłodsi byli szczególnie narażeni na infekcje. Wobec prymitywnej opieki medycznej, choroba oznaczała śmierć. Wyniszczało to psychicznie matki, zmuszone oglądać cierpienie swoich bliskich. Najlepiej rolę Polek scharakteryzował Ludwik Zielonka, warto zacytować jego słowa jako podsumowanie:

Biedne były te nasze szlachetne, zacne i godne Polki! Z jaką wzniosłością ducha, zaparciem siebie i energią znosiły te wszystkie niewygody i nieprzyjemności podróży i życia codziennego. Można śmiało powiedzieć, że my od tych wątłych i słabych istot uczyliśmy się wytrwałości i cierpliwości. One zawsze coś wynalazły, że najsmutniejszego i najbardziej upadłego na duchu umiały pocieszyć i rozweselić, i nieraz same upadając ze znużenia, nigdy nie dawały nam tego poznać, nigdy nie widziano na ich twarzach smutku lub łzy w oku, chociaż miały do zniesienia daleko więcej, bo jako kobiety narażone były na tysięczne nieprzyjemności i niewygody. Z niewypowiedzianą siłą ducha

27 L. Krupecki, Listy zesłańca na Sybir 1863-1865, Tarnów 1998, s. 10.

28 E. Niebelski, Dziewiętnastowieczne dzieje Bogdanowiczów z Nadrybia. Listy z zesłania Jana i Marceliny, Lublin 2005, s. 76. 
pocieszały swych mężów, ojców i nas, zachęcały do wytrwałości, uspokajały zgłodniałe dziatki i chociaż nieraz z rozpaczy i bólu nad dziatwą serce się im krajało, jednak nie pokazywały tego po sobie, a ich uśmiechnięte anielskie oblicza nacechowane łagodnością i dobrocią, przeświecały nam w tej ciężkiej wędrówce życia naszego, a korząc się z niemi przed Majestatem Bożym, spoglądaliśmy weselej i swobodniej w naszą przyszłość.

Dzięki wam za to, czcigodne towarzyszki niedoli i podróży, a jak nam tam przyświecałyście waszą anielską czystością i dobrocią, tak i tutaj w naszej wspólnej ojczyźnie bądźcie gwiazdą jej odrodzenia i przyszłego szczęścia. Wychowujcie wasze dziatki, które na bezludnej, lodowatej przestrzeni Sybiru pierwszy raz światło ujrzały, które ledwo przyszedłszy na Boży świat, nosiły już w sobie znamiona piętna, kajdan i niewoli, nie umiejąc jeszcze chodzić i szczebiotać, otoczone już były rzędem bagnetów i pik kozackich, na takich synów i córki naszej biednej Polski, jak wy byłyście niemi ${ }^{29}$.

\section{BIBLIOGRAFIA}

\section{Opracowania}

Caban W., Dom syberyjski polskich zesłańców politycznych w latach czterdziestych-siedemdziesiątych XIX wieku, [w:] idem, Powstanie styczniowe. Polacy i Rosjanie w XIX wieku. Wybór studiów z okazji czterdziestolecia pracy naukowej i 65 rocznicy urodzin, Kielce 2011, s. 369-378.

Dybowski E., Pamiętnik, Warszawa 2017.

Felińska E., Wspomnienia z podróży do Syberii, pobytu w Berezowie i Saratowie, Wilno 18521853, t. 1-3.

Gembicka-Trębicka S., Na nieznane losy. Między Ołońcem a Jadryniem. Dwa pamiętniki z zesłania po powstaniu styczniowym, oprac. A. Brus, Warszawa 1999.

Kaczyńska E., Syberia największe więzienie świata (1815-1914), Warszawa 1991.

Krupecki L., Listy zesłańca na Sybir 1863-1865, Tarnów 1998.

Michalska-Bracha L., Syberyjskie doświadczenia Polek w świetle materiałów Marii Bruchnalskiej-zarys problematyki, [w:] Polacy w nauce, gospodarce i administracji na Syberii w XIX i na początku XX wieku, red. A. Kuczyński, Wrocław 2007, s. 131-138.

Niebelski E., Dziewiętnastowieczne dzieje Bogdanowiczów z Nadrybia. Listy z zesłania Jana i Marceliny, Lublin 2005.

Obuchowska-Morzycka M., Pamiętniki, [w:] J. Klijanienko-Pieńkowski, Pan Pieńkowski? Da, oni zili zdieś... Wołyń, Syberia, Nałęczów, losy ziemiaństwa na podstawie dokumentów rodzinnych, Stalowa Wola 2012, s. 86-422.

Prendowska J., Moje wspomnienia, Kraków 1962.

${ }^{29}$ L. Jastrzębiec Zielonka, Wspomnienia..., s. 278. 
Śliwowska W., Polska - Syberia. Dwa światy w oczach polskich zesłanek, [w:] Polska a Syberia. Spotkanie dwóch Światów. Materiały z konferencji naukowej. Łódź 1-2 marca 2001 roku, Łódź 2001, s. 191-200.

Śliwowska W., Polskie zesłanki na Syberię w dobie międzypowstaniowej, „Miscellanea Historico-Archivistica" 1996, t. 6, s. 175-183.

\author{
Wojciech Cedro
}

\title{
WOMEN AND CHILDREN'S JOURNEYS OF EXILED TO SIBERIA AFTER JANUARY'S UPRISING
}

\footnotetext{
$\mathrm{T}$ he exile to Siberia was one of the most severe punishment in the Russian Empire's penal law. Sentenced Poles had to journey thousands kilometres heading East. Besides convicted men, Polish women were exiled as well because of their political activities or personal decision. Indeed, some of Polish women decided to go to Siberia in order to accompany their sentenced husbands or relatives. The history of Polish exiles has not sufficiently been elaborated in historiography.

Journey to exile with children is one of the most significant issue in "feminine journeys" topic. Women had to cope with many problems while their journey to Siberia. Among the identified problems were: food's difficulties, illness, bad living conditions as well as bad attitude of Russian officials.

The aim of this article is to describe the conditions of women's journeys to Siberia. It is focused of their motivation and dedication. Their devotions and often commitments often saved the life of their babies and families.
}

Keywords: exile, Siberia, Polish women in XIX century, feminine journey. 